\title{
In memoriam Antunu Petaku (1940. - 2021.)
}

U rujnu nas je iznenada zauvijek napustio naš dragi kolega i prijatelj Antun Petak, čija je karijera obilježila razvoj Instituta za društvena istraživanja u Zagrebu.

Antun Petak rođen je 1940. godine u mjestu Bedenec pored Ivanca. Osnovnu školu završio je u Ivancu, a gimnaziju u Varaždinu. Na Filozofskom fakultetu Sveučilišta u Zagrebu diplomirao je psihologiju. Pohađao je prvi poslijediplomski studij iz sociologije organiziran u Hrvatskoj (1967./1968.), pod nazivom Sociologija razvojnih procesa jugoslavenskog društva, u organizaciji Filozofskog fakulteta Sveučilišta u Zagrebu i Instituta za društvena istraživanja Sveučilišta u Zagrebu.

Prvo radno mjesto bilo mu je u Institutu za društvena istraživanja Sveučilišta u Zagrebu, gdje se zaposlio 1967. godine, najprije kao asistent u Odjelu za fundamentalna sociološka istraživanja. Od toga datuma čitav svoj radni vijek kontinuirano sudjeluje $\mathrm{u}$ organiziranju i provođenju znanstvenih istraživanja u Institutu. Tijekom četrdeset godina radnoga staža koje je proveo u Institutu kolega Petak sudjelovao je u više od 40 znanstvenoistraživačkih projekata. Objavio je preko 130 znanstvenih i stručnih radova iz područja sociologije znanosti i sociologije kulture. Oformio je prvu radnu grupu za istraživanje znanosti u Hrvatskoj.

Bio je član uredništtva časopisa za društvena pitanja Naše teme te glavni i odgovorni urednik časopisa Revija za sociologiju (1974. - 1978.). Suradnik časopisa Sociologija sela / Sociologija i prostor bio je od njegovih početaka, a početkom 2000-ih bio je i glavni i odgovorni urednik časopisa (2002. - 2006.).

Bio je direktor Instituta u razdoblju od 1978. do 1982. godine.

Širinom znanstvenog interesa, teorijskom i metodološkom fundiranošću, organiziranošću i sistematičnošću te rijetkom energijom i entuzijazmom, kolega Petak dao je velik i značajan doprinos razvoju Instituta. I nakon odlaska u mirovinu pratio je naš rad i bio je jedan od rijetkih naših umirovljenika koji je dolazio baš na svaku obljetnicu i proslavu, uvijek dobro raspoložen i spreman na druženje i razgovor.

Nedostajat će nam. Iskreno suosjećamo s njegovom obitelji. 